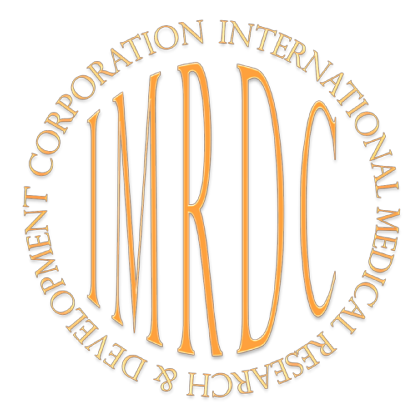

\title{
Comparative Analysis of in vitro Performance of Total-Etch and Self-Etch Adhesives
}

\author{
Timur V. Melkumyan, $\mathrm{PhD}, \mathrm{ScD}$ *; Diloro J. Kakhkharova; \\ Anjela D. Dadamova; Nuriddin Kh. Kamilov; Sitora Sh. Siddikova; \\ Shakhlo I. Rakhmatullaeva; Seyederfan M. Masouleh \\ Tashkent State Dental Institute \\ Tashkent, Uzbekistan
}

\begin{abstract}
The aim of the study was in vitro assessment of shear bond strength and micro-leakage after application of total-etch and self-etch adhesive systems.

Materials and Methods: Four adhesive systems were chosen for assessment of adhesion performance: Contax (DMG, $\mathrm{GmbH}$ ), Bond Force (Tokuyama Dental Corp. Japan Mfr), Te-Econom Bond (Ivoclar Vivadent, Liechtenstein) and Swisstec SL Bond (Coltene, Switzerland). The assessment of bond strength was performed on 20 tooth samples, which were prepared in accordance with the UltraTest technique for shear bond strength (SBS) estimation. The test was conducted at a crosshead speed of $1.0 \mathrm{~mm} / \mathrm{min}$ and results were fixed in kilograms. The assessment of SBS was performed on enamel and dentin separately. Microleakage assessment of self-etch and total-etch adhesive systems was performed on 20 extracted non-carious upper human premolars with immersion in $1 \%$ methylene blue solution after thermocycling.

Results: Good SBS results and microleakage values on the dentin substrate were obtained after application of the Contax self-etch bonding agent. But the values of bond strength to enamel and the extent of dye penetration within the composite-enamel interface were still better with the total-etch approach. (Int J Biomed. 2016; 6(4):283-286.)
\end{abstract}

Key words: adhesive technique $\bullet$ enamel $\bullet$ dentin $\bullet$ shear bond strength $\bullet$ micro-leakage

\section{Introduction}

In dentistry, the etch-and-rinse technique is still considered to be the gold standard of the bond strength of adhesives to enamel. ${ }^{[1]}$ Many studies have demonstrated that if there is a large area of available enamel to be bonded and only a small area of dentin, the total-etch technique is the preferred alternative since it has been shown to result in a stronger bonding to enamel than the self-etch technique. ${ }^{[2,3]}$ Conversely, if a preparation side has a substantial area of dentin to be bonded and a lesser area of enamel, the group of self-etch adhesives is more often preferred. ${ }^{[4,5]}$

The self-etch adhesive technique, in comparison to total-etch, creates a thinner hybrid layer and mainly relies on the formation of multiple chemical bonds between active

*Corresponding author: Timur V. Melkumyan, PhD, ScD. Tashkent State Dental Institute; Tashkent, Uzbekistan.

E-mail: t.dadamov@gmail.com groups of monomer and calcium ions of hydroxyl apatite, and less on collagen fiber hybridization. ${ }^{[6-9]}$ The thinner hybrid layer may be the reason for poor resistance to debonding stresses. In addition, several studies have indicated a decrease in the adhesion strength of self-etch adhesive systems, which might be largely associated with the chemical instability of the material composition. ${ }^{[10,11]}$

The chemical instability of self-etch adhesive materials also indicates the need for strict storage conditions. Many of them should be refrigerated. Also, the storage during shipment and transportation is not always as prescribed. Thus, many factors may account for bad bond strength after a bonding agent application.

The adhesion performance of total-etch and selfetch bonding agents is of clinical importance. Many studies have indicated that in the total-etch approach the successful hybridization of an etched dentin substrate is not always predictable, whereas in the self-etch technique the strength of composite adhesion to enamel is often questionable. ${ }^{[12-16]}$ 
The aim of the study was in vitro assessment of shear bond strength and micro-leakage after application of total-etch and self-etch adhesive systems.

\section{Materials and Methods}

All adhesive procedures were performed by the same operator in accordance with the manufacture's protocol. In each case, the light activation was done using a halogen lightcuring unit (Bluephase 20i (G2), Ivoclar Vivadent) with a light intensity around $700 \mathrm{~mW} / \mathrm{cm} 2$.

Four adhesive systems were chosen for assessment of adhesion performance: Contax (DMG, GmbH), Bond Force (Tokuyama Dental Corp. Japan Mfr), Te-Econom Bond (Ivoclar Vivadent, Liechtenstein) and Swisstec SL Bond (Coltene, Switzerland). Chemical composition of used adhesive systems is presented on Table №1.

Table 1.

Chemical composition of adhesive systems

\begin{tabular}{|l|l|l|}
\hline \multicolumn{1}{|c|}{ Bonding agent } & $\begin{array}{c}\text { Type of } \\
\text { system }\end{array}$ & \multicolumn{1}{|c|}{ Composition } \\
\hline Contax (DMG, GmbH) & Self-Etch & $\begin{array}{l}\text { Contax-Primer: water, } \\
\text { carboxylic acid, sodium fluoride. } \\
\text { Contax-Bond: Hydrophilic and } \\
\text { acidic Bis-GMA-based resin } \\
\text { matrix, catalyst. }\end{array}$ \\
\hline $\begin{array}{l}\text { Bond Force (Tokuyama } \\
\text { Dental Corp. Japan Mfr.) }\end{array}$ & Self-Etch & $\begin{array}{l}\text { Phosphoric acid monomer (3D- } \\
\text { SR monomer), Bis-GMA, 3G } \\
\text { (TEGDMA), HEMA, Alcohol, } \\
\text { Water, Camphorquinone }\end{array}$ \\
\hline $\begin{array}{l}\text { Te-Econom Bond } \\
\text { (Ivoclar Vivadent, } \\
\text { Liechtenstein) }\end{array}$ & Total-Etch & $\begin{array}{l}\text { HEMA, di- and monometha- } \\
\text { crylates, inorganic fillers, } \\
\text { initiators, stabilizers, alcohol } \\
\text { solution }\end{array}$ \\
\hline $\begin{array}{l}\text { Swisstec SL Bond } \\
\text { (Coltene, Switzerland) }\end{array}$ & Total Etch & $\begin{array}{l}\text { Methacrylates, polyalkenoate } \\
\text { methacrylized }\end{array}$ \\
\hline
\end{tabular}

The composite filling material of choice for the application of Contax and Bond Force was palfique ESTELITE paste; for Te-Econom Bond - Te-Econom Plus and Swisstec SL Bond, we used the Swisstec light curing composite.

The assessment of bond strength was performed on 20 tooth samples, which were prepared in accordance with the UltraTest technique for shear bond strength (SBS) estimation. The test was conducted at a crosshead speed of $1.0 \mathrm{~mm} / \mathrm{min}$ and results were fixed in kilograms. Tooth samples (Fig. 1a and Fig. 1b) were divided into two groups: Group $1(n=10)$ for the assessment of SBS on enamel, and Group $2(n=10)$ for the assessment of SBS on dentin.

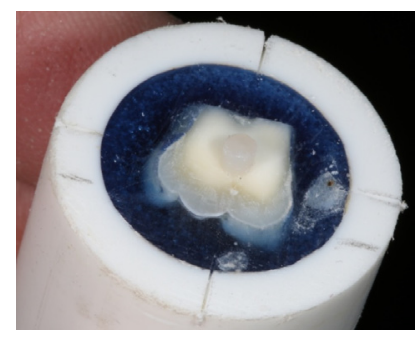

Fig. 1a. Tooth sample for SBS test on dentin

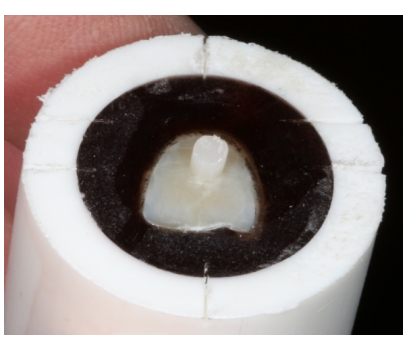

Fig. 1b. Tooth sample for $S B S$ test on enamel
Each sample of both groups was subjected to the 4 following SBS tests (in accordance with the number of adhesives under the study) and every consecutive test was performed after grinding off the remnants of the existing bonded area.

Microleakage assessment of self-etch and total-etch adhesive systems was performed on 20 extracted non-carious upper human premolars. Round artificial cavities $(3 \mathrm{~mm}$ in diameter, $1 \mathrm{~mm}$ deep) were prepared on two approximal surfaces of each tooth with half in enamel and another half in root dentin. All samples were randomly divided into two groups: Group A for assessment of microleakage at the enamel margin, and Group B for assessment of microleakage at the dentin margin. Artificial cavities were filled with composite, polished, and thermocycled (500 cycles in separate water baths of $5^{\circ} \mathrm{C}$ and $65^{\circ} \mathrm{C} \pm 2^{\circ} \mathrm{C}$ with a dwell time of 20 seconds in each bath and a transfer time of 1 second). After thermocycling, the apices of tooth samples were sealed with sticky wax and coated with nail varnish, with the exception of the restoration site and a $1 \mathrm{~mm}$ distance around of it. The teeth were stained in $1 \%$ methylene blue solution for 24 hours and sectioned through the centers of restorations (Fig.2).

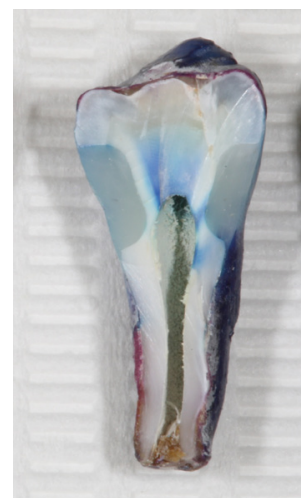

Fig. 2. Microleakage assessment
Enamel and dentin dye penetration (DP) was assessed using the following scale of $0-3$ scoring system:

0 - no DP

1 - DP up to one-half of the cavity wall length

2 - DP up to the full length of the cavity wall, not including the axial wall

3 - DP to the full extent of the cavity wall, including the axial wall
Statistical analysis was performed using StatSoft Statistica v6.0. The mean (M) and standard deviation (SD) were calculated. Multiple comparisons were performed with oneway ANOVA and post-hoc Tukey HSD test. A probability value of $P<0.05$ was considered statistically significant.

\section{Results}

According to obtained SBS test results (Table 2), the enamel bonding capacity of Contax was not as strong as that of Te-Econom Bond and Swisstec SL Bond, but differences in values were not statistically significant. But with the dentin substrate, the bonding capacity of Contax was better (2.8 times) than that of Swisstec SL Bond $(P=0.000)$. At the same time, the average microleakage value of Contax to a dentin tissue was 5 times better than that of Swisstec SL Bond $(P=0.0119)$.

The bonding capacity of Bond Force to enamel or dentin hard tissues was 1.42 and 1.66 times lower, respectively, than the capacity of Te-Econom $(P=0.0202$ and $P=0.0001)$. Microleakage parameters of the compared bonding agents 
in relation to enamel surface were 2.44 times better for TeEconom than for Bond Force $(P=0.0111)$. Thus, good SBS results and microleakage values on the dentin substrate were obtained after application of the Contax self-etch bonding agent. But the values of bond strength to enamel and the extent of dye penetration within the composite-enamel interface were still better with the total-etch approach.

\section{Discussion}

\section{Table 2.}

Shear bond strength and micro-leakage values of total-etch and self-etch adhesive systems under study

\begin{tabular}{|c|c|c|c|c|}
\hline $\begin{array}{l}\text { Bonding agent, } \\
\text { LOT, exp date, } \\
\text { time of test running }\end{array}$ & Group 1 & Group 2 & Group A & Group B \\
\hline $\begin{array}{l}\text { Contax }(\mathrm{DMG}, \\
\text { GmbH), } \\
\text { LOT 743584, } \\
2018-02, \\
27.11 .2016 \\
\quad(1) \\
\end{array}$ & $10.56 \pm 3.26$ & $12.49 \pm 1.72$ & $1.1 \pm 1.0$ & $0.3 \pm 0.48$ \\
\hline $\begin{array}{l}\text { Bond Force } \\
\text { (Tokuyama Dental } \\
\text { Corp. Japan Mfr.), } \\
\text { LOT } 313 \text { MM, } \\
\text { 2019-06, } 27 . \\
11.2016 \\
\quad \text { (2) }\end{array}$ & $8.71 \pm 2.34$ & $7.92 \pm 2.95$ & $2.2 \pm 0.79$ & $0.5 \pm 0.53$ \\
\hline $\begin{array}{l}\text { Te-Econom Bond } \\
\text { (Ivoclar Vivadent, } \\
\text { Liechtenstein), } \\
\text { LOT V11012, } \\
2018-09,26 \text {. } \\
\begin{array}{c}11.2016 \\
\text { (3) }\end{array}\end{array}$ & $12.4 \pm 1.63$ & $13.14 \pm 2.17$ & $0.9 \pm 0.99$ & $1.1 \pm 0.99$ \\
\hline $\begin{array}{l}\text { Swisstec SL } \\
\text { Bond (Coltene, } \\
\text { Switzerland), LOT } \\
\text { G43043, 2018-08, } \\
28.11 .2016 \\
\text { (4) } \\
\end{array}$ & $12.4 \pm 3.18$ & $4.42 \pm 2.1$ & $0.5 \pm 0.7$ & $1.5 \pm 1.09$ \\
\hline $\begin{array}{l}\text { ANOVA } \\
\text { Tukey HSD } \\
\text { Post-hoc Test }\end{array}$ & $\begin{array}{l}\mathrm{P}_{1}=0.0106 \\
\mathrm{P}_{1-2}=0.4251 \\
\mathrm{P}_{1-3}=0.4299 \\
\mathrm{P}_{1-3}=0.4299 \\
\mathrm{P}_{2-3}=0.0202 \\
\mathrm{P}_{-2-4}=0.0202 \\
\mathrm{P}_{3-4}=\mathrm{NaN}\end{array}$ & $\begin{array}{l}\mathrm{P}=0.0000 \\
\mathrm{P}_{1-2}=0.0004 \\
\mathrm{P}^{1-2}=0.9191 \\
\mathrm{P}^{1-3}=0.0000 \\
\mathrm{P}_{2-3}=0.0001 \\
\mathrm{P}^{2-4}=0.0079 \\
\mathrm{P}_{3-4}=0.0000\end{array}$ & $\begin{array}{l}\mathrm{P}_{1}=0.0009 \\
\mathrm{P}_{1-2}=0.0393 \\
\mathrm{P}_{1-3}=0.9565 \\
\mathrm{P}_{1-3}=0.4333 \\
\mathrm{P}_{2-3}=0.0111 \\
\mathrm{P}_{-2-4}=0.0006 \\
\mathrm{P}_{3-4}=0.7407\end{array}$ & $\begin{array}{l}\mathrm{P}=0.0086 \\
\mathrm{P}_{1-2}=0.9469 \\
\mathrm{P}^{1-2}=0.1466 \\
\mathrm{P}^{1-4}=0.0119 \\
\mathrm{P}_{2-3}=0.3702 \\
\mathrm{P}^{2-4}=0.0457 \\
\mathrm{P}_{3-4}=0.6961\end{array}$ \\
\hline
\end{tabular}

Strong adhesion of composite to tooth substrates may be of primary importance for the long-term stability of a tooth colored restoration. However, high values of SBS are not always associated with long-term stability of a toothcomposite interface. ${ }^{[17,18]}$ Deep adhesive tags, which are usually produced by total-etch adhesives, help to provide the initial stability. However, the formation of zones of incomplete infiltration is more likely for the same total-etch bonding agent because of dimensional weakness of a denuded dentin collagen network. ${ }^{[19,20]}$

The presence of micro-cracks on a surface of dentin or enamel may also lead to the formation of longer adhesive tags in those zones, which can be of great benefit in the beginning. However, micro-cracks are prone to microleakage, which could be the main reason for bond degradation in the end.

In this study, an accurate assessment of a bond failure pattern was not undertaken. But preliminary visual analysis of macro images of torn-off surfaces, estimation of the extent of micro-leakage in tooth samples, and SBS test results demonstrated that the Contax 2-bottle self-etch adhesive system $(\mathrm{DMG}, \mathrm{GmbH})$ is a reliable bonding agent in relation to a long-term prognosis. In addition, it was shown that totaletch adhesives adhered better to enamel.

\section{Competing interests} interests.

The authors declare that they have no competing

\section{References}

1. Van Meerbeek B, De Munck J, Yoshida Y, Inoue S, Vargas M, Vijay P, et al. Buonocore memorial lecture. Adhesion to enamel and dentin: current status and future challenges.Oper Dent. 2003 May-Jun;28(3):215-35.

2. Manuja N1, Nagpal R, Pandit IK. Dental adhesion: mechanism, techniques and durability. J Clin Pediatr Dent. 2012 Spring;36(3):223-34.

3. Katz JL, Bumrerraj S, Dreyfuss J, Wang Y, Spencer P. Micromechanics of the dentin/adhesive interface. J Biomed Mater Res. 2001;58(4):366-71.

4. Sundfeld RH, Valentino TA, de Alexandre RS, Briso AL, Sundefeld ML. Hybrid layer thickness and resin tag length of a self-etching adhesive bonded to sound dentin. J Dent. 2005;33(8):675-81.

5. Tay FR, Pashley DH. Aggressiveness of contemporary self-etching systems. I: Depth of penetration beyond dentin smear layers. Dent Mater. 2001;17(4):296-308.

6. Owens BM; Johnson WW; Harris EF. Marginal permeability of Self-etch and total etch adhesive systems. Oper Dent.2006; 31(1): 60-7.

7. Yoshida Y, Nagakane K, Fukuda R, Nakayama Y, Okazaki M, Shintani H, et al. Comparative study on adhesive performance of functional monomers. J Dent Res. 2004; 83(6):454-8.

8. Van Landuyt KL, Snauwaert J, De Munck J, Peumans M, Yoshida Y, Poitevin A, et al.. Systematic review of the chemical composition of contemporary dental adhesives. Biomaterials 2007;28(26):3757-85.

9. Zanchi $\mathrm{CH}$, Munchow EA, Ogliari FA, de Carvalho RV, Chersoni S, Prati C, Demarco FF, Piva E. A new approach in self-etching adhesive formulations: replacing HEMA for surfactant dimethacrylate monomers. J Biomed Mater Res B Appl Biomater. 2011; 99(1):51-7.

10. Breschi L, Mazzoni A, Ruggeri A, Cadenaro M, Di Lenarda R, De Stefano Dorigo E. Dental adhesion review: Aging and stability of bonded interface. Dent Mater. 2008;24(1):90-101. 11. Fujita K, Nishiyama N. Degradation of single bottle type self-etching primer effectuated by the primer's storage period. Am J Dent 2006, 19(2):111-4.

12. Strassler HE. Applications of total-etch adhesive bonding. Compend Contin Educ Dent. 2003; 24(6):427-36.

13. Van Meerbeek B, Yoshihara K, Yoshida Y, Mine A, De Munck J, Van Landuyt KL. State of the art of self-etch adhesives. Dent Mater. 2011;27(1):17-28.

14. Milia E1, Cumbo E, Cardoso RJ, Gallina G. Current 
dental adhesives systems. A narrative review. Curr Pharm Des. 2012;18(34):5542-52.

15. Murdock-Kinch CA, McLean ME. Minimally invasive dentistry. J Am Dent Assoc. 2003;134(1):87-95.

16. Christensen GJ. The advantages of minimally invasive dentistry. J Am Dent Assoc. 2005;136(11):1563-5.

17. Van Meerbeek B, Peumans M, Poitevin A, Mine A, Van Ende A, Neves A, et al. Relationship between bond-strength tests and clinical outcomes. Dent Mater 2010;26(2):e100-21.
18. Tagami J1, Nikaido T, Nakajima M, Shimada Y. Relationship between bond strength tests and other in vitro phenomena. Dent Mater. 2010;26(2):e94-9.

19. Hashimoto M, Fujita S, Nagano F, Ohno H, Endo K. Ten-years degradation of resin-dentin bonds. Eur J Oral Sci. 2010;118(4):404-10.

20. De Munck J, Van Meerbeek B, Yoshida Y, Inoue S, Vargas M, Suzuki K, et al. Four-year water degradation of total-etch adhesives bonded to dentin. J Dent Res. 2003;82(2):136-40. 